\title{
Macrophomina phaseolina: density and longevity of microsclerotia in soybean root tissues and free on the soil, and competitive saprophytic ability
}

\author{
Erlei Melo Reis ${ }^{1,2}$, Cristiane Boaretto ${ }^{1}$ and Anderson Luiz Durante Danelli ${ }^{1,3}$
}

\begin{abstract}
${ }^{1}$ Faculdade de Agronomia e Medicina Veterinária, Universidade de Passo Fundo, Passo Fundo, RS - Brazil; ${ }^{2} \mathrm{CNPq}$ Fellow; ${ }^{3} \mathrm{Capes} / \mathrm{Prosup} / \mathrm{UPF}$ Fellow

Autor para correspondência: Erlei Melo Reis (erleireis@upf.br)

Data de chegada: 28/08/2013. Aceito para publicação em: 13/05/2014 .
\end{abstract}

$10.1590 / 0100-5405 / 1921$

\begin{abstract}
Reis, E. M.; Boaretto, C.; Danelli, A. L. D. Macrophomina phaseolina: density and longevity of microsclerotia in soybean root tissues and free on the soil, and competitive saprophytic ability. Summa Phytopathologica, v.40, n.2, p.128-133, 2014.

In field experiments, the density of Macrophomina phaseolina microsclerotia in root tissues of naturally colonized soybean cultivars was quantified. The density of free sclerotia on the soil was determined for plots of crop rotation (soybean-corn) and soybean monoculture soon after soybean harvest. M. phaseolina natural infection was also determined for the roots of weeds grown in the experimental area. To verify the ability of $M$. phaseolina to colonize dead substrates, senesced stem segments from the main plant species representing the agricultural system of southern Brazil were exposed on naturally infested soil for 30 and 60 days. To quantify the sclerotia, the methodology of Cloud and Rupe (1991) and Mengistu et al. (2007) was employed. Sclerotium density, assessed based on colony

forming units (CFU), ranged from 156 to $1,108 / \mathrm{g}$ root tissue. Sclerotium longevity, also assessed according to CFU, was 157 days for the rotation and 163 days for the monoculture system. M. phaseolina did not colonize saprophytically any dead stem segment of Avena strigosa, Avena sativa, Hordeum vulgare, Brassica napus, Gossypium hirsutum, Secale cereale, Helianthus annus, Triticosecale rimpaui, and Triticum aestivum. Mp was isolated from infected root tissues of Amaranthus viridis, Bidens pilosa, Cardiospermum halicacabum, Euphorbia heterophylla, Ipomoea sp., and Richardia brasiliensis. The survival mechanisms of M. phaseolina studied in this paper met the microsclerotium longevity in soybean root tissues, free on the soil, as well as asymptomatic colonization of weeds.
\end{abstract}

Additional keywords: Glycine max, inoculum density, charcoal root rot, saprophytic survival.

\section{RESUMO}

Reis, E. M.; Boaretto, C.; Danelli, A. L. D. Macrophomina phaseolina: Densidade e longevidade de microescleródios em tecidos radicais da soja e livres no solo e habilidade de competição saprofítica. Summa Phytopathologica, v.40, n.2, p.128-133, 2014.

Em experimentos conduzidos no campo quantificou-se a densidade de microescleródios de Macrophomina phaseolina nos tecidos radicais de cultivares de soja, naturalmente colonizadas. A densidade de escleródios livres no solo foi determinada em parcelas de rotação de culturas (soja-milho) e de monocultura de soja, tendo início logo após a colheita da soja. Determinou-se a ocorrência de infecção natural de $M$. phaseolina em raízes de plantas invasoras ocorrentes na área experimental. Na verificação da capacidade de M. phaseolina colonizar substratos mortos, foram expostos no solo naturalmente infestado por 30 e 60 dias, segmentos de hastes mortas das principais espécies vegetais integrantes do sistema agrícola do sul do Brasil. Na quantificação dos escleródios, utilizou-se a metodologia de Cloud e Rupe (1991) e Mengistu et al. (2007). A densidade de escleródios, avaliada por unidades formadoras de colônias (UFC), variou de 156 a 1.108/g de tecido radicial. A longevidade dos escleródios, avaliados pela UFC, foi de 157 dias na rotação e 163 na monocultura. M. phaseolina não colonizou saprofiticamente nenhum segmento morto, de hastes de Avena strigosa, Avena sativa, Hordeum vulgare, Brassica napus, Gossypium hirsutum, Secale cereale, Helianthus annus, Triticosecale rimpaui, e de Triticum aestivum. $M p$ foi isolado de tecidos radiciais infectados de Amaranthus viridis, Bidens pilosa, Cardiospermum halicacabum, Euphorbia heterophylla, Ipomoea sp., e Richardia brasiliensis. Os mecanismos de sobrevivência de $M$. phaseolina estudados nesse trabalho contemplaram a longevidade de microeslceródios em tecidos radiciais da soja, livres no solo e a colonização assintomática de plantas daninhas.

Palavras-chave adicionais: Glycine max, densidade de inóculo, podridão cinzenta da raiz, sobrevivência saprofítica.

Soybean [Glycine max (L.) Merr.] fields in Brazil reached 27 million hectares in the $2012 / 13$ growing season (5). The soybean is mostly grown under monoculture and no-tillage system, which favors the occurrence and the severity of a large number of diseases.

Root rots caused by Rhizoctonia solani Kühn., Macrophomina phaseoli (Tassi) Goidanish and Fusarium tucumaniae Aoki, O'Donnell, Homma, Lattanzy, are among the most important soybean diseases (28).

Macrophomina root rot (MRR), gray root rot, or charcoal root rot is the most common and widely spread root disease affecting soybean 
crops throughout the Brazilian fields. Plants grown on infested soybean fields show "uneven ripening" and the most severe cases may result in dead plant patches. MRR is caused by Macrophomina phaseolina.

The disease development is favored by high air temperatures (30$\left.35^{\circ} \mathrm{C}\right)(16)$, soil moisture stress (15), high seedling stand (18), plant injury (4), flowering and seedling stages (19), and soybean monoculture (7). Soybean root infection may start from two to three weeks after seedling emergence. Primary infections may remain latent until the occurrence of environmental stress such as soil water deficit and high air temperature, coinciding with R1-R7 growth stages.

The pathogen survives primarily in the form of sclerotium free on the soil or as a sclerotium inside diseased plant tissues. Macrophomina phaseolina $(\mathrm{Mp})$ is a soil-borne facultative parasite of low competitive saprophytic ability (CSA), i.e., it is easily suppressed by the activities of competitive, antagonistic and/or hyperparasitic soil microflora (7). However, $M p$ microsclerotium survival and competitive saprophytic ability on the soil and under the weather at southern Brazil is not known in detail.

Researchers, technical assistants and producers are concerned about the occurrence and the damage caused by MRR to soybeans, especially regarding the absence of resistant cultivars and the low control efficiency of other practices.

The disease severity in soybean farms at southern Brazil was highest in the 2009/10 growing season. The highest occurrence and severity were found for plants close to the ripening stage, under water stress and high air temperature. Yield losses of up to $50 \%$ have been reported in the north of Paraná State, Brazil (9).

$M p$ inoculum sources on the soil were hypothesized to be maintained and replaced by root colonization of susceptible hosts. Microsclerotium density (SD) on the soil could be reduced by means of crop rotation with non-susceptible crops, but the presence of symptomless weeds can harbor and replace the inoculum on the soil.

This study was focused on $M p$ inoculum sources. Thus, the density of microsclerotia in root tissues or free on the soil was assessed, as well as their longevity and fungal competitive saprophytic ability, and presence of weeds harboring the fungus in the roots.

\section{MATERIAL AND METHODS}

\section{Microsclerotium density in root tissues of soybean cultivars}

A field trial was carried out in the 2010 growing season, in Sertão RS, to assess a soybean field at growth stage R7 using four replicates. The roots of soybean cultivars 'Apolo', 'Ativa', 'Energia', 'Força', 'Impacto', 'Magna', 'Turbo', Fundacep 53, 57, 58, 62 e 63, 'Coodetec', and 'Coodetec' 243 from ten plants at R7 growth stage were randomly sampled from each plot.

Microsclerotia in root tissues were quantified by following the methodologies of Cloud and Rupe's (6) and Megistu et al. (17). Roots and lower stems were cut, washed in tap water and dried at $40^{\circ} \mathrm{C}$ in a forced aeration oven for seven days to kill the mycelium. Dried tissues were ground in a mill (Wiley, Model 4) and passed through a $1.0-\mathrm{mm}$ mesh sieve. Four $0.25 \mathrm{mg}$ milled tissue samples/plot were stirred in a blender with $100 \mathrm{~mL}$ of $0.525 \% \mathrm{NaOCl}$ for three minutes to kill the mycelia, passed through a $53 \mu \mathrm{m}(270 \mathrm{mesh})$ sieve and washed with sterile water. The suspension was added to $100 \mathrm{~mL}$ potato dextrose agar (PDA), cooled at $55^{\circ} \mathrm{C}$, mixed with rifampicin $(100 \mathrm{mg} / \mathrm{L})$ and metalaxyl (224 mg/L (without Tergitol), and poured at $15 \mathrm{~mL}$ per plate, with five replicates $(6,17)$. Plates were incubated at $30^{\circ} \mathrm{C}$ in the dark for seven days, and the inoculum density was rated according to the colony forming units (CFU)/g of soil.

Data were subjected to analysis of variance and means were compared according to Scott-Knot test $(\mathrm{p}=0.05)$.

Microsclerotium longevity in naturally infected soybean root tissues

Soybean root samples were collected from the experimental area of University of Passo Fundo, RS, Brazil (UPF). The soybean crop was cultivated in plots under no-tillage and in rotation with corn and in monoculture for 15 years. Ten plants per plot were harvested at monthly intervals and their whole root system was removed from the soil with the aid of a small shovel in four replicates.

The methodology of Cloud and Rupe (6) and Mengistu et al (17) was used to quantify microsclerotium density (SD) in root tissues, as previously described.

Data are expressed as number of CFU per gram of root tissue and subjected to analysis of variance and regression.

\section{Longevity of free microsclerotia on naturally infested soil}

Soil from the experimental area at UPF was sampled at monthly intervals; 10 subsamples were collected per plot, at the soil top 0.5 cm layer.

\section{Competitive saprophytic ability}

Dead plant tissues of different plant species buried in naturally infested soil (Experiment 2 site) in the field were assessed for $M p$ ability to colonize the plant tissues.

Avena strigosa Schreb, white oats Avena sativa L., Hordeum vulgare L., Brassica napus L., Gossypium hirsutum L., Secale cereale L., Helianthus annus L., Triticosecale rimpaui Wittm, and wheat Triticum aeativum L. were grown in a greenhouse to obtain healthy plants. At flowering stage, green stems were collected, cut into $3-4 \mathrm{~cm}$ long pieces, and dried at $45^{\circ} \mathrm{C}$ in an oven up to constant weight. Fifty stem pieces of each plant species were stored in nylon mesh $(30 \times 30 \mathrm{~cm})$ bags mixed with $100 \mathrm{~g}$ of soil taken from Experiment 2 site, showing a density of 5.6 to $8.2 \mathrm{CFU} / \mathrm{g}$ soil. Bags were buried at $10 \mathrm{~cm}$ depth in the same site of the field and removed after an exposure time of 30 and 60 days; in the laboratory, stem pieces were thoroughly washed under tap water, disinfested with sodium hypochlorite and rinsed twice with sterile water. Five small stem pieces $(5 \mathrm{~mm})$ of each plant species were plated on semi-selective medium (dehydrated potato-dextrose-agar 39 g, metalaxyl $224 \mathrm{mg}$ i.a., rifampicin $100 \mathrm{mg} / \mathrm{L}$ water), $15 \mathrm{~mL} /$ Petri dish, incubated for five days in the dark at $30^{\circ} \mathrm{C}$, and $\mathrm{Mp}$ incidence (mycelium and microsclerotia) in the medium was determined.

\section{Natural infection of weed roots}

Asymptomatic weed plants, at or after flowering, were sampled from UPF experimental area (Experiment 2) during the 2009/10 and 2010/11 soybean growing seasons. Plants were removed from the soil with a small shovel and taken to the lab. Roots were washed under tap water, were cut into $5 \mathrm{~mm}$ long pieces, had their surface disinfested with sodium hypochlorite, and were plated part on water-agar and part on $1 / 4 \mathrm{PDA}+500 \mathrm{mg} / \mathrm{L}$ streptomycin sulfate.

\section{RESULTS AND DISCUSSION}

Microsclerotium density in root tissues of soybean cultivars

All plants showed MRR symptoms and signs but at different intensities among cultivars. The latter were separated into three reaction 
groups according to Scott-Knot's test. CFU density ranged from 156 to $1,108 / \mathrm{g}$ root tissue. Cultivars 'Magna', 'Força' and 'Fundacep' 58 showed the lowest CFU, while 'Energia' and 'Coodetec' 243 had the highest CFU density (Table 1). The inoculum density in the roots seems not to relate to the maturation group; 'Energia' fits in group 5.0, showing 1,040 CFU/g, while 'Coodetec' 243 had 1,108 CFU/g tissue, fitting in group 8.0.

Little is known about the reaction of the evaluated cultivars to MRR, and the maturity group seems to have no effect. The differences may be due to their tolerance to MRR. Mengistu et al. (17) found up to 5,000 $\mathrm{CFU} / \mathrm{g}$ tissue, a much higher result than our findings.

\section{Microsclerotium longevity in soybean root tissues under natural field conditions}

Microsclerotia completely lost their viability in soybean root tissue over a period of 157 days. In southern Brazil, soybean is harvested from April to May and reseeded in October/November, six to seven months later.

There was no difference between monoculture and rotation regarding the CFU densities $\left(\mathrm{R}^{2}=0.88\right)$. According to the equations, microsclerotium population reached zero at 157 days under rotation and at 163 days under monoculture, after burial (Fig. 1).

Free microsclerotia on the soil are released during root decomposition and their density can increase with years of soybean monoculture (7). In southern Brazil, complete decomposition of soybean residue occurs in 35 months after harvest (21). Thus, during this span, microsclerotia is released on the soil. The number of seasons with a susceptible crop in monoculture probably increases $M p$ density on the soil. For example, $80 / \mathrm{g}$ in the first growing season reached $120 / \mathrm{g}$ in the second season, $149 / \mathrm{g}$ at the end of the third, reaching $165 / \mathrm{g}$ of soil in the fifth year. Up to 1,000 microsclerotia per gram of soil have been quantified (21).

According to Mengistu et. al (17), CFU-based SD in root tissues can be used to assess the reaction of soybean cultivars to $M p$ in the selection of resistance.

Microsclerotia rated by $\mathrm{CFU}$ in the roots lost their viability in 157 days, as well as those free on the soil, which were subjected to soil microorganism competition. In our study, microsclerotia were embedded in the root tissue and thus protected from the soil antagonists. Nevertheless, their longevity was 163 days, shorter than the time required for root tissue decomposition, which is 35 months (21).

\section{Longevity of free sclerotia on natural soil}

CFU was lower on the soil than in the root tissues. In the first sampling, in June, ID was 4.8 to $6.0 \mathrm{CFU}$, which then increased between July and August in response to decomposition and release of sclerotia on the soil, reaching $11.3 \mathrm{CFU} / \mathrm{g}$ soil.

Between October and November, CFU were not retrieved from the soil, reaching zero/g soil. This may evidence the low CSA. After soybean harvest, microsclerotia may be released from infected roots onto the soil for up to 35 months (21), but those present in the root tissues lose their viability within six months, as shown in our study (Fig. 2). If the longevity of microsclerotia free on the soil was assessed in the same site of the field, and if this viability period was longer than that determined here, there might be another inoculum origin such as weed roots. $M p$ probably survives on the soil for a long period, not due to microsclerotium longevity, but to their wide host range, especially weeds.

ID was much higher for the roots than for the inoculum free on the soil.

\section{Competitive saprophytic ability (CSA)}

The used methodology did not allow detecting the CSA of $M p$ to colonize dead stem tissues of the most common crops in southern Brazil when buried on naturally infested soil. There was not saprophytic colonization of any stem segment of any plant species at 30 and 60 days of tissues exposure to soil inoculum. $M p$ density on this soil was 5.6/g CFU/g soil in September 2011; 7.0/g CFU/g soil in November 2011/12; and 8.2/g CFU/g soil in November 2012. Thus, regardless of the plant species, canola, barley, rye, black oat, rape and wheat were not saprophytically colonized under natural soil inoculum. Canola is the only species that has been reported to be susceptible to $M p$ as a natural host in Argentina (10), although it was not saprophytically colonized.

The method commonly used to determine the CSA of soilborne fungi consists in exposing suitable substrates to colonization by the fungus on naturally infested non-sterile soil $(7,12,20)$. In the present study, the soil was from a soybean monoculture farm that had been cultivated for more than 10 years, and plants showed a MPP root incidence higher than $50 \%$ every season. The exposed substrates were the main plant species grown in the regional agricultural system, except for cotton. Thus, a wide range of substrates with different nutritional compositions and $\mathrm{C} / \mathrm{N}$ ratio was available for $M p$. If $M p$ had CSA, it would have colonized one or more substrates but, as a saprophyte, the fungus showed no success in competing for the substrate.

Moreover, $M p$ likely survives on the soil for long periods, which is not due to its CSA but to its wide range of hosts, specially weeds. $M p$ has 1,408 plant hosts (http://nt.ars-grin.gov/funagaldatabaes/ index $/ \mathrm{cfm}$ ). The presence of $M p$ on the soil cannot be attributed only to microsclerotium longevity on the soil (153days), or to the fungus CSA, but the presence of weed hosts able to maintain, increase and replace the inoculum on the soil has to be considered. In some farms, the weed population is great.

According to Dhingra \& Sinclair (7), $M p$ has weak CSA. Buried pieces of dead plant tissues did not produce mycelium or microsclerotia

Table 1. Macrophomina phaseolina density in root tissues of soybean cultivars rated according to colony forming units (CFU)

\begin{tabular}{ccc}
\hline Cultivars & $\begin{array}{c}\text { Maturation } \\
\text { group }\end{array}$ & $\begin{array}{c}\text { Microsclerotia density } \\
\text { in root tissue (CFU/g) }\end{array}$ \\
\hline Fundacep 63 & 4.9 & $732 \mathrm{~b}$ \\
Energia & 5.0 & $1,040 \mathrm{a}$ \\
Apolo & 5.5 & $404 \mathrm{c}$ \\
Ativa & 5.6 & $864 \mathrm{~b}$ \\
Impacto & 5.8 & $672 \mathrm{~b}$ \\
Turbo & 5.8 & $796 \mathrm{~b}$ \\
Fundacep 62 & 5.8 & $888 \mathrm{~b}$ \\
Magna & 6.2 & $156 \mathrm{~d}$ \\
Força & 6.2 & $172 \mathrm{~d}$ \\
Coodetec & 6.4 & $364 \mathrm{c}$ \\
Fundacep 53 & 6.4 & $480 \mathrm{c}$ \\
Fundacep 57 & 6.7 & $640 \mathrm{~b}$ \\
Fundacep 58 & 6.8 & $180 \mathrm{~d}$ \\
Coodetec 243 & 8.0 & $1,108 \mathrm{a}$ \\
\hline & $\mathrm{CV}(\%)$ & 26.7 \\
\hline
\end{tabular}

Means of four replicates, five subsamples per plot followed by the same letter are not different according to Scott-Knott's test at $\mathrm{p}=0.05$ 


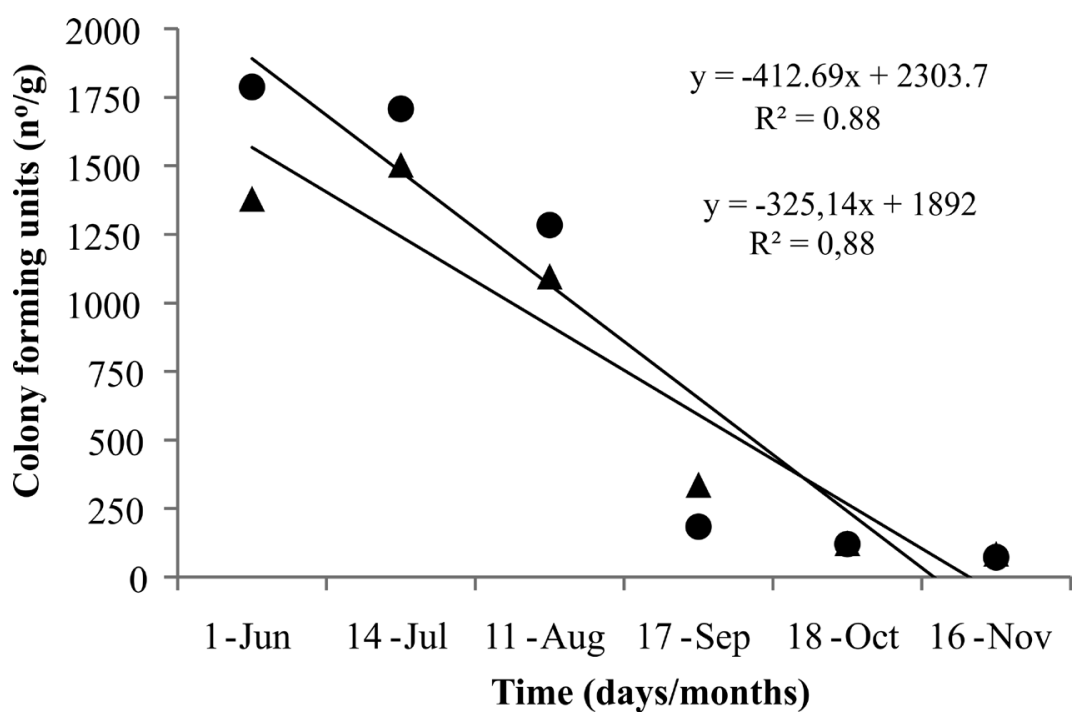

Figure 1. Longevity of Macrophomina phaseolina in soybean root tissues rated according to colony forming units with time after soybean harvest $(\bullet$ - soybean monoculture; $\boldsymbol{\Delta}$ - soybean - corn rotation).

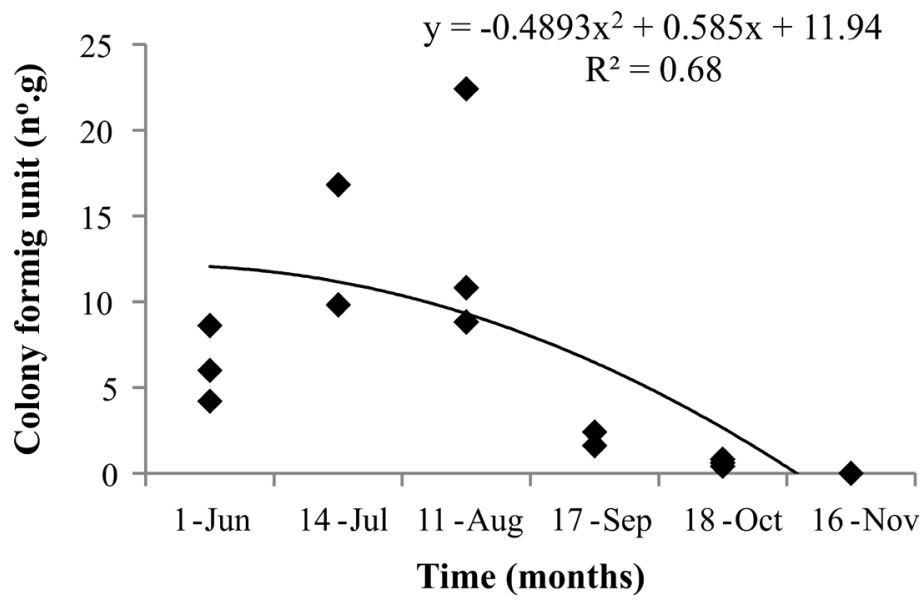

Figure 2. Longevity of Macrophomina phaseolina free on the soil rated according to colony forming units with time after soybean harvest.

in the semi-selective medium. In the present study, plant stem segments were not colonized by the fungus at 30 and 60 days after burring in the infested soil, an enough period for saprophytic colonization.

$M p$ is a soil-borne facultative parasite of low CSA; thus, it is easily suppressed by the activities of competitive antagonistic soil microflora (7). Rao (20) used the agar plate method, a modification of the 'Cambridge method', to estimate CSA. Using this method, saprophytes of intermediate ability were Bipolaris sorokiniana (Sacc.) Shoem. and M. phaseoli.

\section{Natural colonization of weed plants by $M p$}

Weed plant species at UPF experimental area are also common among farms in southern Brazil. The fungus was isolated from roots of all sampled plant species (Table 2) not showing any secondary symptom. Only primary, less evident symptoms, such as small lesions in the root fragments showing microsclerotium-like structures, were found.
Symptomless plants such as Polygonum hydropiperoides Michx, Amaranthus viridis L., Euphorbia heterophylla L., Conyza sp., Sida spp., Richardia brasiliensis Gomes, Ipomoea sp., Cardiospermum halicacabum L., Bidens pilosa L., Xanthium cavanillesii Schouw were sampled in the summer and $M p$ was isolated from their roots (Table 2).

The pathogen survives primarily in the form of sclerotia free on the soil or in diseased plant tissues and symptomless weed plants. A large number of sclerotia are produced in host tissues and subsequently dispersed on the soil during tillage or decaying of plant residues (23).

The inoculum maintenance on the soil is due to the colonization of roots of susceptible live plant species. Soil-borne inocula increase by multiplying in the roots during the plant cycle from seedling to the mature plant; they are released during root decomposition and wait for a susceptible host to start a new infection cycle. In the present study, microsclerotia lost their viability in six months (Fig. 1), shorter than soybean stems, which fully decomposed in 35 months under no-tillage (21), before the decomposition of crop residues. The breakdown of 
Table 2. Above-ground symptomless weed species harboring Macrophomina phaseolina in root lesions

\begin{tabular}{|c|c|c|c|c|c|c|c|c|}
\hline \multirow[b]{2}{*}{ Host } & \multicolumn{2}{|c|}{ Fusarium spp. } & \multicolumn{6}{|c|}{ M. phaseolina } \\
\hline & $1^{\mathrm{z}}$ & 2 & 3 & 4 & 1 & 2 & 3 & 4 \\
\hline Amaranthus viridis & $\mathrm{x}$ & $\mathrm{x}$ & - & - & - & - & - & $\mathrm{x}$ \\
\hline Bidens pilosa & $\mathrm{x}$ & $\mathrm{x}$ & - & - & - & $\mathrm{x}$ & - & - \\
\hline Cardiospermum halicacabum & - & - & - & - & - & - & - & $\mathrm{x}$ \\
\hline Conyza sp. & $\mathrm{x}$ & $\mathrm{x}$ & - & - & - & - & - & - \\
\hline Euphorbia heterophylla & $\mathrm{x}$ & $\mathrm{x}$ & - & - & - & $\mathrm{x}$ & - & - \\
\hline Ipomoea sp. & - & - & - & - & - & - & $\mathrm{x}$ & - \\
\hline Polygonum hydropiperoides & $\mathrm{x}$ & $\mathrm{x}$ & - & - & - & - & - & - \\
\hline Richardia brasiliensis & $\mathrm{x}$ & $\mathrm{x}$ & - & - & - & $\mathrm{x}$ & - & - \\
\hline Sida spp. & $\mathrm{x}$ & $\mathrm{x}$ & - & - & - & - & - & \\
\hline Xanthium cavanillesii & - & $\mathrm{x}$ & - & - & - & - & - & - \\
\hline
\end{tabular}

$\left.{ }^{2}\right)$ - sampling time: first $01 / 11 / 2011$, second $01 / 21 / 2011$, third $02 / 22 / 2011$, fourth $03 / 04 / 2011$. - infected, - not infected.

host tissues was more slowly (35 months) than the microsclerotium viability loss (157 days).

Soil inoculum can be inferred to reduce without the replacement of sclerotia in the soil bank. Rotation of non-susceptible crops could lead $M p$ ID to reduce if other mechanisms for inoculum introduction, maintenance and replacement were not present.

In the present experiment, $M p$ did not show ability to colonize dead tissues of the main crops of the farming system in southern Brazil; thus, it can be classified as a weak saprophyte, in agreement to Dhingra and Sinclair (1976).

In the farming system in southern Brazil, there are no shortage of susceptible host plants to $\mathrm{Mp}$; therefore, inocula are maintained, multiplied and replaced in cultivated and/or weed hosts season after season.

The inoculum reduction/elimination on cultivated soils is not feasible for farmers who do not stop growing susceptible species like beans, corn, cotton, sorghum, soybeans, i.e., the most profitable crops under monoculture and no-tillage system.

\section{REFERENCES}

1. Almeida, A. M. R.; Torres, E.; Farias, J. R. B.; Benato, L.C.; Pinto, M.C.; Marin, S. R. R. Macrophomina phaseolina em soja: sistema de semeadura, sobrevivência em restos cultura e diversidade genética. Londrina: Embrapa Soja, 2001. 47 p.

2. Andrus, C.F. Seed transmission of Macrophomina phaseoli. Phytopathology, St Paul, v. 28, p. 620-634, 1938.

3. Bristow, P.R; Wyllie, T.D. Reaction of soybean cultivars to Macrophomina phaseolina as seedlings in growth chamber and field. MO Academy of Science, Maryville, v.18, p. 5-10, 1984

4. Canaday, C.H.; Helsel, D.G.; Wyllie, T.D. Effects of herbicide-induced stress on root colonization of soybean by Macrophomina phaseolina. Plant Disease, St Paul, v.70, n.9, p. 863-866, 1986.

5. Companhia Nacional de Abastecimento. Brasília , DF, 2013 Disponível em $<$ http://www.conab.gov.br/>Acesso em : 25 jan. 2013.

6. Cloud, G. L.; Rupe, J.C. Comparison of three media for enumeration of sclerotia of Macrophomina phaseolina. Plant Disease, St Paul, v.75, n.8, p.771-772, 1991.

7. Dhingra, O. D.; Sinclair, J. B. Biology and pathology of Macrophomina phaseolina. Viçosa. Imprensa Universitária, UFV, $1978.166 \mathrm{p}$.

8. Dhingra, O. D.; F.D. Tenne and J.B. Sinclair. Method for the determination of competitive saprophytic colonization of soil fungi. Transactions of the British Mycological Society, Cambridge, v. 66, n. 3, p. 447-456, 1976.

9. Ferreira, L.P.; Lehman, P.S.; Almeida, A.M.R. Doenças da soja no Brasil.
Londrina: Circular técnica. 1979.

10. Gaetán, S A.; Fernandez, L.; Madia, M. Occurrence of charcoal rot caused by Macrophomina phaseolina on canola in Argentina. Plant Disease, St Paul, v. 90, n. 4, p.524, 2006.

11. Gangopadhyay, S.; Wyllie, T. D.; Luedders, V. D. Macrophomina phaseolina seed transmitted in soybeans. Plant Disease Reporter, St Paul, v. 54, n.10, p. 1088-1091, 1970.

12. Garrett, S. D. Ecology of the root inhabiting fungi. Biological Reviews, Cambridge, vol. 25, n. 2, p. 220-254, 1950.

13. Kunwar, I.K.; Singh, J. Location, survival, transmission and management of seed-borne Macrophomina phaseolina, causing charcoal rot in soybean. Back $\leftarrow$ Abstract $\downarrow$ Descriptors $\downarrow$ Top $\uparrow$ Annals of Plant Protection Sciences, New Delhi, v. 8, n. 1, p. 44-46, 2000

14. Kunwar, I.K.; Singh, T.; Machado, C.C.; Sinclair, J.B. Histopathology of soybean seed and seedling infection by Macrophomina phaseolina. Phytopathology, St Paul, v. 76, n.5, p. 532-535,1986.

15. Magalhães, A.A. de; Choudhury, M. M.; Millar, A.A. Albuquerque, M. M. Effect of water deficit on Macrophomina phaseolina of bean. Pesquisa Agropecuária Brasileira, Brasília, DF, v. 17, n.3, p. 407-411, 1982.

16. Manici, L.M.; Caputo, F.; Cerato, C . Temperature responses of isolates of Macrophomina phaseolina from different climate regions of sunflower production in Italy. Plant Disease, St Paul, v.79, n. 8, p. 834-838, 1995

17. Mengistu, A.; Ray, J.D.; Smith, J.R.; Paris, R.L. Charcoal rot disease assessment of soybean genotypes using a colony-forming unit index. Crop Science, Madison, v. 47, n.6, p. 2453-2461, 2007.

18. Pearson, C.A.S.; Schwenk, F.W.; Crowe, F.J. Kelly, K. Colonization of soybean roots by Macrophomina phaseolina. Plant Disease, St Paul, v. 68, n.12, p. 1086-1088, 1984

19. Pratt, R. G. A direct observation technique for evaluating sclerotium germination by Macrophomina phaseolina and effects of biocontrol materials on survival of sclerotia in soil. Mycopathologia, New York, v. 162, n.2, p. 121-131, 2006.

20. Rao, A. S. A comparative study of competitive saprophytic ability in twelve root-infecting fungi by an agar plate method. Transactions of the British Mycological Society, Cambridge, v. 42, n. 1, p. 97-111, 1959.

21. Reis, E. M.; Baruffi, D.; Remor, L; Zanatta, M. Decomposition of corn and soybean residues under field conditions and their role as inoculum source. Summa Phytopathologica, Botucatu, v.37, n.1, p.65-67, 2011.

22. Short, G.E.; Wyllie, T.D.; Ammon, V.D. Survival of Macrophomina phaseolina in soybean tissues. Phytopathology, St Paul, v. 68, n.5, p. 736-741, 1978

23. Short, G. E., Wyllie, T. D.; Bristow, P. R. Survival of Macrophomina phaseolina in soil and residue of soybeans. Phytopathology, St Paul, v. 70, n.1, p. $13-17,1980$.

24. Smith, G.S.; Wyllie, T.D. Charcoal rot. In: Hartman, G.L.; Sinclair, J.B.; Rupe, J.C. APS: St Paul, 1999, p. 29-31.

25. Watanabe, T. Survivability of Macrophomina phaseoli (Maubl.) Asbhy in naturally infested soil and longevity of the sclerotia formed in vitro. Annals of Phytopathological Society of Japan, v. 39, n.4, p. 
333-337, 1973.

26. Wrather, J. A.; Kendig, S. R.; Tyler, D. D. Tillage effects on Macrophomina phaseolina population density and soybean yield. Plant Disease, St Paul, v. 82, n.2, p. 247-250, 1998.

27. Wyllie, T.D.; Calvert, O. H. Effect of flower and pod set on formation of sclerotia and infection of Glycine max by Macrophomina phaseolina. Phytopathology, St Paul, v. 59, n.10, p. 1243-1245, 1969.

28. Yorinori, J.T. Controle integrado das principais doenças da soja. In: Câmara, G.M.S. (Ed.). Soja: tecnologia da produção II. Piracicaba: ESALQ, LPV, 2000. p. 203-221. 